\title{
THE ANALYSIS OF RISK FACTORS AND CLINICAL-DEMOGRAPHIC CHARACTERISTICS OF PATIENTS WITH CLOSTRIDIUM DIFICILLE INFECTION AS WELL AS THE OUTCOME OF THEIR TREATMENT
}

Ivana Rakovic ${ }^{1,2}$, Biljana Popovska Jovicic ${ }^{1,2}$, Andriana Bukonjic ${ }^{2}$, Sara Petrovic ${ }^{2}$, Petar Canovic ${ }^{2}$, Nedim Hamzagic ${ }^{3}$

${ }^{1}$ Clinic of Infectious Disease, Clinical centre Kragujevac, Kragujevac, Serbia

${ }^{2}$ Faculty of Medical Sciences, University of Kragujevac, Kragujevac, Serbia

${ }^{3}$ The general hospital, Department of Nephrology, Tutin, Serbia

\author{
ANALIZA FAKTORA RIZIIKA I KLINIČKO-DEMO GRAFSIKIH \\ KARAKTERISTIKA KOD BOLESNIKA SA CLOSTRIDIUM DIFFICILE \\ INFEKCIJOM KAO I ISHOD NJIHOVOG LEČENJA

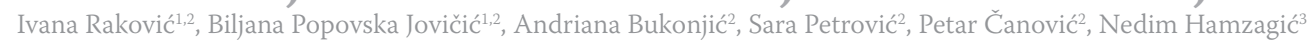 \\ ${ }^{1}$ Klinika za infektivne bolesti, Klinički centar Kragujevac, Kragujevac, Srbija \\ ${ }^{2}$ Fakultet medicinskih nauka, Univerzitet u Kragujevcu, Kragujevac, Srbija \\ ${ }^{3}$ Odsek za nefrologiju, Opšta bolnica Tutin, Tutin, Srbija
}

Received / Primljen: 05. 02. 2016.

Accepted / Prihvaćen: 24. 02. 2016.

\section{ABSTRACT}

Pseudomembranous colitis is a frequent nosocomial infection associated with significant morbidity and mortality. Clostridium difficile infection incidence most frequently increases due to unreasonable antibiotic use and the appearance of new hypervirulent bacterial strains, which leads to prolonged hospitalization and an increase in the total cost of hospital treatment.

This is a retrospective design study conducted at Clinical Centre Kragujevac from January to December 2014. The patient data were obtained from the protocol of the Virological Laboratory and from medical documentation. All statistical analyses were performed using the computer program SPSS. The descriptive statistical data are expressed as percentage values. Continuous variables are expressed as the arithmetic mean with the standard deviation.

Clostridium difficile infection occurred more frequently with elderly patients (123 patients were over 65 years old). Out of 154 patients on antibiotic treatment, 110 patients were treated with a combination of two or more antibiotics from different pharmacological groups. The most represented antibiotics were from the cephalosporin (71.4\%) and quinolone (46.3\%) groups. A total of $85.8 \%$ of the patients used proton pump inhibitors and $\mathrm{H} 2$ blockers.

Our results describe the clinical and demographic characteristics of patients with diagnosed Clostridium difficile infection. The most prevalent characteristics (age, antibiotic therapy, PPI and H2 blocker use), which other researchers have also mentioned as risk factors, were present in our study as well.

Keywords: Clostridium difficile; diarrhoea; antibiotics; proton pump inhibitors; metronidazole; vancomycin

\section{SAŽETAK}

Pseudomembranozni kolitis je česta nozokomijalna infekcija koja je udružena sa značajnim morbiditetom i mortalitetom. Incidenca Clostridium difficile infekcije najčešće se povećava neracionalnom primenom antibiotika i pojavom novog hipervirulentnog soja bakterije što dovodi do produžene hospitalizacije i povećanja ukupne cene bolničkog lečenja.

Istraživanje je retrospektivnog dizajna, spovedeno je u Klinčkom centru Kragujevac u periodu od januara do decembra 2014. godine. Podaci o pacijentima uzeti su iz protokola Virusološke laboratorije i medicinske dokumentacije. Sve statističke analize su uradene u kompjuterskom programu SPSS. Deskriptivni statistički podaci su izraženi u procentima. Kontinuirane varijable su izražene srednjim vrednostima uz podatak o standardnom odstupanju.

Clostridium difficile infekcija češće se javlja kod pacijenata starije životne dobi (123 pacijenta preko 65 godina). Od 154 pacijenta koji su tretirani antibiotskom terapijom, 110 pacijenata je lečeno kombinacijom dva ili više antibiotika iz različite farmakološke grupe. Najviše zastupljeni antibiotici su bili iz grupe cefalosporina $(71,4 \%)$ i hinolona $(46,3 \%)$. Kod $85,8 \%$ pacijenata primenjivani su inhibitori protonske pumpe i H2 blokatori.

Naši rezultati obuhvataju kliničko-demografske karakteristike pacijenata sa dijagnostikovanom Clostridium difficile infekcijom. U najvećem procentu su zastupljene one karakteristike (starost, antibiotska terapija, primena IPP $i$ H2 blokatore) koje su i drugi istraživači naveli kao faktore rizika.

Ključne reči: Clostridium difficile; dijareja; antibiotik; inhibitori protonske pumpe; metronidazol; vankomicin 


\section{INTRODUCTION}

Pseudomembranous colitis is a frequent nosocomial infection associated with significant morbidity and mortality rates. The most frequent colitis-causing pathogen in hospitalized patients is anaerobic, Gram-positive, sporogenous Clostridium difficile bacillus. The clinical spectrum of the disease varies from mild, watery diarrhoea to fulminant pseudomembranous colitis with complications (1).

A great number of studies have shown that exposure to antibiotics is considered the most significant risk factor for the onset of Clostridium difficile infection. Old age; surgical interventions on the gastrointestinal tract; enteral feeding; prolonged hospitalization, especially at intensive care units; chemotherapy; and comorbidity presence can also contribute to the onset of infection (2-4).

With regard to proton pump inhibitor utilization and its association with the onset of Clostridium difficile infection, clinical study data are contradictory. Some clinical studies indicate that there is no significant difference in Clostridium difficile infection incidence during the use of proton pump inhibitors (PPIs) (5), while other studies indicate that there is a three times greater risk of morbidity after PPI utilization $(6,7)$.

The pseudomembranous colitis incidence has increased worldwide due to unreasonable antibiotics utilization and the appearance of new hypervirulent strains of the bacterium. This increase leads to prolonged patient hospitalization and increases the total cost of hospital treatment. The estimated treatment costs are approximately 3 billion $€$ per year (8).

The aim of this study was to determine the clinical and demographic characteristics of patients with clostridial infection as well as the outcome of their treatment.

\section{MATERIALS AND METHODS}

This is a retrospective study conducted at Clinical Centre Kragujevac from January to December 2014. A total of 169 patients diagnosed with Clostridium difficile infection were included. The patient data were obtained from the protocol of the Virological Laboratory, where stool analysis was performed using an enzyme immunoassay test (EIA). Further research included only the patients with positive tests, while the patients with negative tests or incomplete medical documentation were excluded from the study. The following data were collected:

- Socio-demographic characteristics of the patients;

- The patients' health conditions (acute or chronic diseases);

- Results of diagnostic procedures and laboratory analyses;

- Surgical and medicamental observation.

All statistical analyses were performed in the SPSS computer program (version 18). For each continuous variable, the distribution normality was determined, and then the values were expressed as the arithmetic mean with standard deviation. Descriptive statistical data are expressed as percentage values.

\section{RESULTS}

The research included 95 male (56.2\%) and 74 female (43.8\%) patients. The average age of the examinees was 70 (69.9 \pm 12.6$)$. The youngest examinee was 27 , and the oldest was 95 years old. The results demonstrated that Clostridium difficile infection occurred more frequently in elderly patients (123 patients were over 65 years old).

The average hospitalization length was $24.7 \pm 16.3$ days. The infection occurred more frequently in patients hospitalized in internal medicine units (cardiology 16\%, pulmonology $14.8 \%$, neurology $11.8 \%$ ). In the intensive care unit, during 2014, 20 patients (11.8\%) were registered with the above-mentioned symptoms. Diarrheic syndrome developed after 15 days of hospitalization $(14.7 \pm 10.4)$. The patients formed three to four stools a day on average.

Most of the patients were on antibiotic treatment (91.12\%). For 11 patients (6.5\%), there were no data about antibiotic consumption, while 4 patients $(2.4 \%)$ were not receiving antibiotic treatment during or immediately before hospitalization. Most of the patients were receiving a combination of two or more antibiotics from a different group in the ATC Classification System (Table 1).

Within the group of those receiving combined antibiotic therapy, 48 patients $(43.6 \%)$ were treated with cephalosporins and quinolones, 38 (34.5\%) patients were treated with cephalosporins, and $10(9.1 \%)$ patients used quinolones as one of the antibiotics in their treatment. A total of 14 patients (12.7\%) on combined antibiotic therapy did not use antibiotics from either the cephalosporin or the quinolone group.

Antibiotics from the cephalosporin (71.4\%) and quinolone (46.3\%) groups were most the highly used for antibiotic therapy. Third-generation cephalosporins and levofloxacin were the most frequently administered (Table 2).

Table 1. Pharmacotherapeutic groups of antibiotics administered to patients with Clostridium difficile infection

\begin{tabular}{|c|c|c|c|}
\hline ATC & $\begin{array}{c}\text { Pharmacotherapeutic } \\
\text { groups of antibiotics }\end{array}$ & Patients $\left(\mathbf{N}^{\circ}\right)$ & Patients (\%) \\
\hline J01C & Penicillins & 1 & 0.7 \\
\hline J01D & Cephalosporins & 19 & 12.9 \\
\hline J01DH & Carbapenems & 4 & 2.7 \\
\hline J01G & Aminoglycosides & 2 & 1.4 \\
\hline J01M & Quinolones & 10 & 6.8 \\
\hline J01A & Tetracyclines & 1 & 0.7 \\
\hline J01 & CAT** & 110 & 74.8 \\
\hline \multicolumn{2}{|c|}{ Total } & 147 & 100 \\
\hline
\end{tabular}

*A combination of two and/or more antibiotics from a different pharmacological group.

${ }^{\text {f}}$ For 7 patients the administered antibiotic is not known. 
Table 2. The presence of antibiotics from cephalosporin and quinolone groups

\begin{tabular}{|c|c|c|c|c|c|}
\hline $\begin{array}{c}\text { Pharmacotherapeutic groups } \\
\text { of antibiotics }\end{array}$ & ATC & Antibiotics & Patients $\left(\mathbf{N}^{\circ}\right)$ & Patients (\%) & Patients $(\%)^{\odot}$ \\
\hline \multirow{6}{*}{ Cephalosporins } & J01DB & $1^{\text {st }}$ generation & 8 & 7.6 & 4.7 \\
\hline & J01DC & $2^{\text {nd }}$ generation & 7 & 6.7 & 4.1 \\
\hline & J01DD & $3^{\text {rd }}$ generation & 73 & 69.5 & 43.2 \\
\hline & J01DE & $4^{\text {th }}$ generation & 3 & 2.9 & 1.8 \\
\hline & J01D & Combination $^{ \pm}$ & 14 & 13.3 & 8.3 \\
\hline & \multicolumn{2}{|c|}{ Total } & 105 & 100 & 62.1 \\
\hline Quinolones & J01MA12 & Levofloxacin & 36 & 52.9 & 15.0 \\
\hline \multicolumn{2}{|l|}{ J01MA02 } & Ciprofloxacin & 28 & 41.2 & 11.7 \\
\hline & J01MA & Combination $^{*}$ & 4 & 5.9 & 1.7 \\
\hline & \multicolumn{2}{|c|}{ Total } & 68 & 100 & 28.3 \\
\hline
\end{tabular}

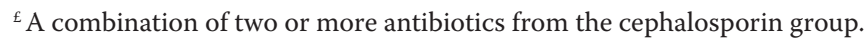

¥ A combination of levofloxacin and ciprofloxacin.

- The percentage of incidence out of the total number of patients (169).

The average length of antibiotics use (for 125 patients) was $16.2 \pm 11.5$ days.

PPIs were used by $47(27.8 \%)$ patients and $\mathrm{H} 2$ blockers were used by $55(32.5 \%)$ patients. Both drugs were used by $43(25.4 \%)$ patients, while 24 patients did not use any of the drugs from the given pharmacological groups.

A total of 155 patients $(91.72 \%)$ were treated with antibiotics to eliminate Clostridium difficile bacillus. In eradication therapy, metronidazole alone or a combination of metronidazole and vancomycin were the most frequently used (Table 3).

Out of 58 patients on combined eradication therapy, 45 patients $(77.6 \%)$ were first treated with metronidazole and then vancomycin, while 13 patients (22.4\%) simultaneously used both antibiotics.

Pulmonography was performed on 129 patients. Out of that number, pleural effusion occurred in 38 patients $(29.5 \%)$.

The presence of free fluid was visualized by ultrasound in 23 patients (35.4\%), although echogram of the abdomen was performed on 65 patients.

Disease relapse occurred in 19 patients (11.2\%). A total of $32(18.9 \%)$ patients passed away, mostly due to comorbidity.

\section{DISCUSSION}

The results of the study show a statistically significant connection between the onset of clostridial infection and the patient's age. Previous studies have shown that the infection develops more frequently in elderly patients (2), and elderly patients composed $72.8 \%$ of the examinees included in our study.

Hospitalization for longer than fifteen days is considered one of the risk factors for developing Clostridium difficile infection $(3,9)$. Prolonged treatment, especially in intensive care units, increases the risk by nearly two-fold (3). The average hospitalization length in our study was longer than 15 days $(24.7 \pm 16.3)$, and the intensive care unit was one of the most frequent departments (11.8\%) where the infection developed. However, the department structure's significance for clostridial infection onset cannot be observed as an isolated statistic variable considering that there are differences between departments in regard to antibiotics consumption and the inpatients' age.

Antibiotics use increases the onset incidence of Clostridium difficile infection by about seven times (10). The highest risk for the development of clostridial infection is the use of clindamycin, quinolone, cephalosporin, monobactam and carbapenem, which have risk factors that are similar to that of multiple antibiotics utilization, as well as their long-lasting use $(10,11)$. Meta-analysis conducted on 30184 patients during 2013 showed that cephalosporin and quinolone use increased the risk by five to six times (10). Macrolides, trimethoprim-sulfamethoxazole and penicillins have less influence on the infection onset (10, 11). In most cases, our patients were treated with combined antibiotics therapy (Table 1.). The most frequently applied antibiotics were $3^{\text {rd }}$-generation cephalosporins and antibiotics from the quinolone group (Table 2), which are, according to studies, the most influential in triggering Clostridium difficile infection. The average length of antibiotics utilization was approximately 16 days.

With regard to the significance of PPI use in the onset of Clostridium difficile infection, data obtained from clinical studies are contradictory. A meta-analysis that included 39 studies showed a statistically significant association

Table 3. Eradication therapy of Clostridium difficile infection

\begin{tabular}{|c|c|c|}
\hline Antibiotics & Patients $\left(\mathbf{N}^{\circ}\right)$ & Patients $(\%)$ \\
\hline Metronidazole tbl. & 58 & 34.9 \\
\hline Vancomycin amp. & 39 & 23.5 \\
\hline Combined eradication therapy $^{2}$ & 58 & 34.9 \\
\hline Without eradication therapy & 11 & 6.6 \\
\hline
\end{tabular}

f-For 3 patients (1.78\%) the data about eradication therapy are missing. ${ }^{\partial-}$ Metronidazole (amp. and tbl.) and vancomycin (amp.). 
between PPI use and the development of Clostridium difficile infection (6). According to studies, the incidence of the disease is two to three times higher in patients treated with PPIs than in patients who were not treated with PPIs $(6,12)$, while the use of $\mathrm{H} 2$ blockers increases this risk by two-fold (12).

Studies conducted during 2011 and 2012 did not show an influence of PPI use on the onset of this infection (5). In our study, only $14.2 \%$ of the examinees received neither PPIs nor $\mathrm{H} 2$ blockers.

Recurrent infection is expressed by repeated manifestations of disease symptoms 14 to 60 days after a previous episode of infection. Relapse after initial antibiotic therapy is manifested in $20-30 \%$ of patients (13). Feldman and associates established that infection relapse is the result of reinfection by new bacterial strains (14). Repeated infection occurred in $11.2 \%$ of our patients. Some patients with recurring disease were probably cured at regional hospitals, so the total number of recurrent infections is probably higher.

The mortality rate for Clostridium difficile infection in numerous studies varies from $13 \%$ to $27 \%(15,16)$. Comorbidity of congestive heart diseases, chronic pulmonary diseases, renal insufficiency, malignant neoplasms, inflammatory bowel diseases (Crohn's disease, ulcerative colitis), and diabetes mellitus are all associated with worse outcomes and a higher mortality rate among hospitalized patients with Clostridium difficile infection (17, 18). Our results show that mortality was mostly caused by comorbidity.

The treatment of Clostridium difficile infection depends on the severity of clinical conditions and includes metronidazole and/or vancomycin use along with other substitution and symptomatic therapy. A meta-analysis (1218 patients) has indicated that metronidazole and vancomycin provide similar cure rates in patients in mild clinical condition, while vancomycin is more effective at treating patients in severe clinical condition (19). In severe clinical condition cases, $97 \%$ of the patients treated with vancomycin were cured, in comparison to $76 \%$ of those treated with metronidazole (20). Combined eradication therapy and the independent use of metronidazole were administered for the highest number of patients (Table $3)$. However, because this was a retrospective study design and the data about the severity of the clinical condition were inaccessible, it cannot be confirmed whether the appropriate treatment protocol was followed. Patients who were not on combined eradication therapy during hospitalization either passed away immediately after being diagnosed or their treatment was continued at authorized health institutions.

\section{CONCLUSION}

Clostridium difficile is a very significant pathogen causing hospital-acquired diarrhoea. The disease affects mostly elderly, hospitalized patients with comorbidities. It appears most frequently after cephalosporin and fluoroquionolone use. Treatment depends on the severity of the clinical condition and relies on metronidazole and/or vancomycin utilization along with other substitution and symptomatic therapy.

Our study included only patients with diagnosed Clostridium difficile infection. The presented results include the clinical and demographic characteristics of these patients. The most prevalent characteristics (age, antibiotic therapy, PPI and H2 blocker use), which other researchers have also mentioned as risk factors, are present in our study as well.

\section{REFERENCES}

1. Moudgal V, Sobel JD. Clostridium difficile colitis: a review. Hosp Pract (1995). 2012; 40(1): 139-48.

2. Furuya-Kanamori L, Stone JC, Clark J, McKenzie SJ, Yakob L et al. Comorbidities, Exposure to Medications, and the Risk of Community-Acquired Clostridium difficile Infection: a systematic review and meta-analysis. Infect Control Hosp Epidemiol. 2015; 36(2): 132-41.

3. Gao T, He B, Pan Y, Deng Q, Sun H et al. Association of Clostridium difficile infection in hospital mortality: A systematic review and meta-analysis. Am J Infect Control. 2015; 43(12): 1316-20.

4. Goodhand JR, Alazawi W, Rampton D. Systematic review: Clostridium difficile and inflammatory bowel disease. Aliment Pharmacol Ther. 2011; 33(4): 428-41.

5. Bavishi C, DuPont HL. Systematic review: the use of proton pump inhibitors and increased susceptibility to enteric infection. Alimen Pharmacol Ther 2011; 34: 1269-81.

6. Kwok CS, Arthur AK, Anibueze CI, Singh S, Cavallazzi $\mathrm{R}$ et al. Risk of Clostridium difficile infection with acid suppressing drugs and antibiotics: meta-analysis. Am J Gastroenterol. 2012; 107(7): 1011-9.

7. Janarthanan S, Ditah I, Adler DG, Ehrinpreis MN. Clostridium difficile-associated diarrhea and proton pump inhibitor therapy: a meta-analysis. Am J Gastroenterol. 2012; 107: 1001-10.

8. Bauer MP, Notermans DW, van Benthem BH, Brazier JS, Wilcox $\mathrm{MH}$ et al. Clostridium difficile infection in Europe: a hospital-based survey. Lancet. 2011; 377(9759): 63-73.

9. Surowiec D, Kuyumjian AG, Wynd MA, Cicogna CE. Past, present, and future therapies for Clostridium difficile-associated disease. Ann Pharmacother 2006; 40: 2155 - 63.

10. Deshpande A, Pasupuleti V, Thota P, Pant C, Rolston DD et al. Community-associated Clostridium difficile infection and antibiotics: a meta-analysis. J Antimicrob Chemother. 2013; 68(9): 1951-61. 
11. Brown KA, Khanafer N, Daneman N, Fisman DN. Meta-analysis of antibiotics and the risk of communityassociated Clostridium difficile infection. Antimicrob Agents Chemother. 2013; 57(5): 2326-32.

12. Dial S, Alrasadi K, Manoukian C, Huang A, Menzies D. Risk of Clostridium difficile diarrhea among hospital inpatients prescribed proton pump inhibitors: cohort and case-control studies. CMAJ. 2004; 171: 33-8.

13. Kelly CP, LaMont JT. Clostridium difficile--more difficult than ever. N Engl J Med. 2008; 359(18): 1932-40.

14. Tang-Feldman Y, Mayo S, Silva J Jr et al. Molecular analysis of Clostridium difficile strains isolated from 18 cases of recurrent Clostridium difficile -associated diarrhea. J Clin Microbiology 2003; 41: 3413-4.

15. Hookman P, Barkin JS. Clostridium difficile associated infection, diarrhea and colitis. World J Gastroenterol 2009; 15: 1554-80.
16. Arvand M, Hauri AM, Zaiss NH, Witte W, BettgeWeller G. Epidemiology of severe Clostridium difficile infections in Hesse, Germany in 2008-2009. Dtsch Med Wochenschr 2010; 135(40): 1963-7.

17. Goodhand JR, Alazawi W, Rampton D. Systematic review: Clostridium difficile and inflammatory bowel disease. Aliment Pharmacol Ther 2011; 33(4): 428-41.

18. Bajaj JS, O'Leary JG, Reddy KR, Wong F, Olson JC et al. Second infections inde-pendently increase mortality in hospitalized patients with cirrhosis: the North American consortium for the study of end-stage liver disease (NACSELD) experience. Hepatology 2012; 56(6): 2328-35.

19. Di X, Bai N, Zhang X, Liu B, Ni W et al. A meta-analysis of metronidazole and vancomycin for the treatment of Clostridium difficile infection, stratified by disease severity. Braz J Infect Dis. 2015; 19(4):339-49

20. Shafran DM, Shafran SD. Treating Clostridium difficile infection. CMAJ. 2014;186: 7. 


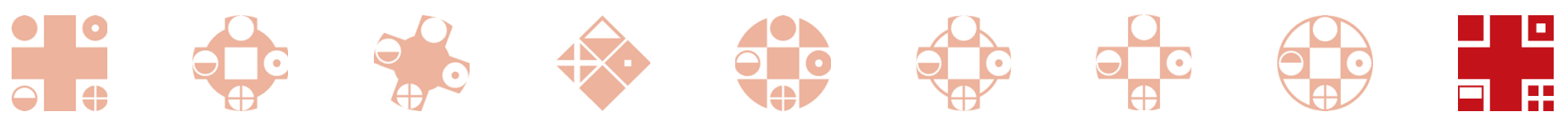

